\title{
Acute Lower Limb Ischemia in Patients Infected with COVID-19
}

This article was published in the following Dove Press journal:

International Journal of General Medicine

\author{
Nabil Al-zoubi (iD \\ Nawaf Shatnawi \\ Hamza Jarbo \\ Department of General Surgery/Vascular \\ Surgery, Jordan University of Science and \\ Technology, Irbid, Jordan
}

Background: The aim of this study was to investigate the prevalence of acute lower limb ischemia (ALLI) among patients infected with COVID-19 and to review their characteristics and outcomes.

Methods: This study was performed at King Abdullah University Hospital (KAUH) in the north of Jordan. All patients with ALLI and COVID-19 infection, between November 1, 2020 and December 31, 2020, were retrospectively identified and reviewed.

Results: A total number of 1300 COVID-19 patients were admitted to KAUH during the period of the study. Seven patients $(0.54 \%)$ had ALLI. Of them, 5 were males $(71.4 \%)$ with a mean age of $68 \pm 3$ years and 2 were females $(28.6 \%)$ with a mean age of $58 \pm 7$ years. Five patients (71.4\%) were admitted as COVID-19 infection and developed ALLI during hospitalization, all of them were males, had COVID-19 related pneumonia, and died within 24 hours of ALLI diagnosis. While 2 patients were presented with ALLI and found to have positive COVID-19, all of them were females, underwent successful thrombo-embolectomy, and had no deaths, however, one of them had recurrent ALLI which resulted in below knee amputation.

Conclusion: The prevalence of ALLI in patients infected with COVID-19 was $0.54 \%$. We observed that patients with COVID-19 related pneumonia who develop ALLI during hospitalization had a high mortality.

Keywords: ALLI, COVID-19, KAUH

\section{Introduction}

Since the identification of first case cluster in Wuhan, China, in December 2019, the COVID-19 pandemic has swept the entire world. ${ }^{1}$ Jordan has more than 294,494 confirmed cases of COVID-19 and almost 3834 deaths since the first reported case of COVID-19 in Jordan on March 2, 2020. Although ALLI is a rare complication of COVID-19, ${ }^{2}$ there have been increasing number of reports of peripheral arterial thrombosis in COVID-19 patients. ${ }^{3}$ At our institution, we also observed that some COVID-19 patients had ALLI. Therefore, this study was performed to investigate the prevalence of ALLI among patients infected with COVID-19 and to review their characteristics and outcomes.

\section{Methods}

This study was approved by IRB of Jordan university of science and technology (JUST) and KAUH. Patient informed consent was not required due to the deidentified data without breach of confidentiality, and that this study was conducted in accordance with the Declaration of Helsinki. It is a single-center study in which
Department of Surgery, Faculty of Medicine, Jordan University of Science and Technology, P.O. Box 3030, Irbid, 22110, Jordan

Tel + 9627955774637

Email dr_nabeil_z3bi@yahoo.com 
Table I Patients Characteristics and Outcomes

\begin{tabular}{|c|c|c|c|c|c|c|c|}
\hline Variable & Pt I & Pt 2 & Pt 3 & Pt 4 & Pt 5 & P 6 & P7 \\
\hline \multicolumn{8}{|c|}{ Demographic Data } \\
\hline Age & 62 & 55 & 60 & 67 & 75 & 75 & 65 \\
\hline Sex & Female & Female & Male & Male & Male & Male & Male \\
\hline $\mathrm{BMI} \mathrm{kg} / \mathrm{m}^{2}$ & 33 & 34 & 33 & 36 & 29 & 24 & 23 \\
\hline \multicolumn{8}{|l|}{ Clinical Data } \\
\hline Presentation & ALLI first & ALLI first & COVID-19 first & $\begin{array}{l}\text { COVID-19 } \\
\text { first }\end{array}$ & $\begin{array}{l}\text { COVID-19 } \\
\text { first }\end{array}$ & $\begin{array}{l}\text { COVID-19 } \\
\text { first }\end{array}$ & $\begin{array}{l}\text { COVID-19 } \\
\text { first }\end{array}$ \\
\hline Site of occlusion & Distal SFA & CFA & Distal Aorta/iliac & Popliteal & CFA & SFA+PFA & SFA \\
\hline $\begin{array}{l}\text { Duration of } \\
\text { Ischemia }\end{array}$ & 10 days & 2 days & & & & & \\
\hline $\begin{array}{l}\text { Duration of } \\
\text { COVID-19 } \\
\text { before ALLI }\end{array}$ & & & 5 days & 3 days & 2 weeks & I week & I week \\
\hline $\begin{array}{l}\text { COVID-19- } \\
\text { related } \\
\text { pneumonia }\end{array}$ & No & No & Yes & Yes & Yes & Yes & Yes \\
\hline $\begin{array}{l}\text { Death within } 24 \\
\text { Hours }\end{array}$ & No & No & Yes & Yes & Yes & Yes & Yes \\
\hline Cause of death & - & - & Respiratory failure & $\begin{array}{l}\text { Respiratory } \\
\text { failure }\end{array}$ & $\begin{array}{l}\text { Respiratory } \\
\text { failure }\end{array}$ & $\begin{array}{l}\text { Respiratory } \\
\text { failure }\end{array}$ & $\begin{array}{l}\text { Respiratory } \\
\text { failure }\end{array}$ \\
\hline Amputation & Yes & No & & & & & \\
\hline DM & No & Yes & Yes & Yes & Yes & No & No \\
\hline HTN & No & Yes & Yes & Yes & Yes & Yes & Yes \\
\hline Hyperlipidemia & No & No & Yes & Yes & Yes & No & No \\
\hline Smoking & Yes & Yes & Yes & No & Yes & Yes & Yes \\
\hline $\begin{array}{l}\text { Chronic Renal } \\
\text { Disease }\end{array}$ & No & No & No & No & No & No & No \\
\hline $\begin{array}{l}\text { Chronic } \\
\text { medications }\end{array}$ & Aspirin & $\begin{array}{l}\text { Gabapentin } \\
\text { Hydroxyurea } \\
\text { Atorvastatin } \\
\text { Thiazide } \\
\text { Aspirin Insulin }\end{array}$ & $\begin{array}{l}\text { Aspirin, insulin } \\
\text { Isosorbid dinitrite } \\
\text { Atorvastatin Atenolol } \\
\text { Enalapril } \\
\text { Carbamezepine } \\
\text { Metformin }\end{array}$ & $\begin{array}{l}\text { Enalapril } \\
\text { Amlodipine } \\
\text { Aspirin, } \\
\text { Lansoprazole } \\
\text { Atorvastatin } \\
\text { Insulin }\end{array}$ & $\begin{array}{l}\text { Atenolol, } \\
\text { Enalapril, } \\
\text { Aspirin, } \\
\text { Metformin } \\
\text { Glimipride }\end{array}$ & $\begin{array}{l}\text { Allopurinol } \\
\text { Atorvastatin, } \\
\text { Furosemide, } \\
\text { Clopidogrel } \\
\text { Irbesartan }\end{array}$ & $\begin{array}{l}\text { Aspirin } \\
\text { Enalapril }\end{array}$ \\
\hline \multirow[t]{2}{*}{$\begin{array}{l}\text { Covid-19 } \\
\text { symptoms }\end{array}$} & \multirow[t]{2}{*}{ Asymptomatic } & \multirow[t]{2}{*}{ Asymptomatic } & $\begin{array}{l}\text { Loss of taste and smell, } \\
\text { General fatigue Fever }\end{array}$ & Hypoxia & Cough Fever & Fever & $\begin{array}{l}\text { Shortness of } \\
\text { breath }\end{array}$ \\
\hline & & & Hypoxia & Fever & $\begin{array}{l}\text { Shortness of } \\
\text { breath }\end{array}$ & $\begin{array}{l}\text { Shortness of } \\
\text { breath }\end{array}$ & Cough \\
\hline $\begin{array}{l}\text { Anticoagulation } \\
\text { prior to ALLI }\end{array}$ & No & No & Prophylactic LMWH & $\begin{array}{l}\text { Prophylactic } \\
\text { LMWH }\end{array}$ & $\begin{array}{l}\text { Prophylactic } \\
\text { LMWH }\end{array}$ & $\begin{array}{l}\text { Prophylactic } \\
\text { LMWH }\end{array}$ & $\begin{array}{l}\text { Prophylactic } \\
\text { LMWH }\end{array}$ \\
\hline
\end{tabular}

(Continued) 
Table I (Continued).

\begin{tabular}{|c|c|c|c|c|c|c|c|}
\hline Variable & Pt I & Pt 2 & Pt 3 & Pt 4 & Pt 5 & P 6 & P7 \\
\hline \multicolumn{8}{|c|}{ Laboratory Tests at time of ALLI diagnosis } \\
\hline $\begin{array}{l}\text { White-cell } \\
\text { count }\end{array}$ & 7.7 & 19.2 & 13.3 & 12.2 & 3.5 & II.I & 10.8 \\
\hline $\begin{array}{l}\text { Total } \\
\text { neutrophils }\end{array}$ & 6822 & 12,400 & 11,438 & 11,102 & 3010 & 9271 & 2378 \\
\hline $\begin{array}{l}\text { Total } \\
\text { lymphocytes }\end{array}$ & 431 & 5376 & 665 & 732 & 315 & 1217 & 788 \\
\hline $\begin{array}{l}\text { Total } \\
\text { monocytes }\end{array}$ & 480 & 9600 & 1037 & 219 & 122 & 558 & 580 \\
\hline Platelet count & 306 & 1430 & 332 & 352 & 190 & 244 & 233 \\
\hline Hemoglobin & 14.1 & 9.7 & 14.5 & 11 & 11.2 & 13.6 & 11.3 \\
\hline $\begin{array}{l}\text { Prothrombin } \\
\text { time }\end{array}$ & 15.3 & 18.2 & 19.2 & 15 & 14.5 & 13 & 16 \\
\hline Fibrinogen & None & None & None & None & None & None & None \\
\hline D-dimer & $>20$ & None & None & None & 5.19 & None & 19 \\
\hline $\begin{array}{l}\text { C-reactive } \\
\text { protein }\end{array}$ & 152.7 & 232.8 & 214.5 & 177 & 65 & None & 100 \\
\hline K & 4.4 & 5.72 & 5.1 & 3.99 & 4 & 3.5 & 4.1 \\
\hline $\mathrm{Na}$ & 137 & 134 & 132 & 137 & 138 & 135 & 139 \\
\hline Urea & 9.1 & 12.8 & 11.4 & 4.7 & 8.2 & 31.7 & 4.8 \\
\hline Creatinine & 118 & 274 & 55 & 75 & 71 & 161 & 133 \\
\hline Albumin & 30.9 & None & 31.7 & 43 & 28.9 & None & 33 \\
\hline Total bilirubin & 7.5 & None & 8.3 & 8.5 & 9.6 & None & 7.9 \\
\hline Direct bilirubin & 3.8 & None & 6.2 & 2.8 & 5.6 & None & 2.3 \\
\hline $\begin{array}{l}\text { Alkaline } \\
\text { phosphatase }\end{array}$ & 67 & None & 87 & 85 & 69 & None & 64 \\
\hline ALT & 21.9 & None & 63.1 & 15.6 & 27.6 & None & 17.4 \\
\hline AST & 31.7 & None & 106.7 & 19.9 & 43 & None & 41 \\
\hline Gamma GT & 21 & None & 241 & 20 & 25 & None & 23 \\
\hline
\end{tabular}

Abbreviations: Pt, patient; SFA, superficial femoral artery; CFA, common femoral artery; PFA, profunda femoris artery; ALLI first, acute lower limb ischemia first presentation; COVID-19 first, coronavirus disease first presentation; LMWH, low molecular weight heparin; BMI, body mass index; DM, diabetes mellitus; HTN, hypertension.

all patients with ALLI at KAUH who diagnosed with COVID-19 (during hospitalization or presented to emergency department) from November 1, 2020 to December 31, 2020 were retrospectively identified and reviewed. Demographic, clinical and laboratory data were analyzed. The diagnosed of COVID-19 was done by nasopharyngeal swab using real-time reversetranscriptase rRT-PCR. ALLI evaluations include history, physical examinations and investigations. The diagnosis of ALLI was done clinically and confirmed by imaging studies. CT-Angiogram (CTA) and arterial duplex U/S were performed to confirm the diagnosis and to plan for 
intervention. Thrombo-prophylaxis was given to all COVID-19 in-patients according to our treatment guidelines. Therapeutic anti-coagulation was immediately started for all patients at the time of ALLI diagnosis. Thrombo-embolectomy was done through standard femoral approach.

\section{Results}

A total number of 1300 COVID-19 patients were admitted to KAUH between November 1, 2020 and December 31, 2020. Seven patients $(0.54 \%)$ had ALLI. Of them, 5 were males $(71.4 \%)$ with a mean age of $68 \pm 3$ years and 2 were females $(28.6 \%)$ with a mean age of $58 \pm 7$ years. Five patients (71.4\%) were admitted as COVID-19 and developed ALLI during hospitalization, all of them were males, had COVID-19 related pneumonia, and died within 24 hours of ALLI diagnosis. While 2 patients were presented with ALLI and found to have positive COVID-19, all of them were females, underwent successful thromboembolectomy, and had no deaths, however, one of them had recurrent ALLI which resulted in below knee amputation. The overall mortality among admitted COVID-19 patients was $26.0 \%$ (338/1300). Of them, 5 patients (1.48\%) had ALLI. Demographic and clinical data are presented in Tables 1 and 2.

\section{Discussion}

ALLI is a sudden decrease in limb perfusion that threatens limb viability and represents a major vascular emergency. ${ }^{4}$

Table 2 Baseline Characteristics in COVID-19 with ALLI and All COVID-19 Patients

\begin{tabular}{|l|c|c|}
\hline & $\begin{array}{c}\text { COVID-19 with } \\
\text { ALLI }(\mathbf{n}=7)\end{array}$ & $\begin{array}{c}\text { All COVID-19 Patients } \\
(\mathbf{n}=1300)\end{array}$ \\
\hline Age, m \pm SD & $65.56 \pm 1.13$ & $39.90 \pm 16.59$ \\
\hline Sex/males & $5(71.42 \%)$ males & $585(45.0 \%)$ males \\
\hline $\begin{array}{l}\text { BMI } \geq 30 \mathrm{~kg} / \\
\mathrm{m}^{2}\end{array}$ & $4(57.14 \%)$ & $401(30.85 \%)$ \\
\hline DM & $4(57.14 \%)$ & $160(12.31 \%)$ \\
\hline HTN & $6(85.71 \%)$ & $273(21.0 \%)$ \\
\hline Hyperlipidemia & $3(42.86 \%)$ & $112(8.62 \%)$ \\
\hline Smoking & $6(85.71 \%)$ & $416(32.0 \%)$ \\
\hline Hypoxia & $5(71.43 \%)$ & $338(26.0 \%)$ \\
\hline
\end{tabular}

Abbreviations: $\mathrm{m} \pm \mathrm{SD}$, mean \pm slandered deviation; BMI, body mass index; DM, diabetes mellitus; HTN, hypertension.
It results from arterial embolus, in situ thrombosis, or bypass graft thrombosis. ${ }^{5}$ The most common etiology of ALLI is an arterial embolism, the majority of the emboli originating in the heart. ${ }^{2}$ It is one of the most common vascular surgery emergencies with significant rates of mortality and limb loss which have traditionally been reported to be as high as $20-40 \%$ and $12-50 \%$, respectively. ${ }^{5}$

Coronavirus is a single-stranded, enveloped RNA virus with a helical capsid. ${ }^{2}$ It was first considered to cause solely respiratory dysfunction; however, various clinical presentations have shown that COVID-19 is a systemic disease, not restricted to the lungs. ${ }^{6}$ Many patients suffered a number of other problems, such as renal failure, cardiac arrhythmia, myocarditis and coagulative disorders. ${ }^{7}$ Thrombotic complications secondary to hypercoagulable state have recently been reported in which pulmonary embolism (PE) was the commonest reported event in patients with COVID-19 on intensive care units. ${ }^{3}$ Although arterial thrombosis involving upper and lower extremity is being noted among COVID-19 patients, multiple retrospective analyses have demonstrated incidents of thrombosis ranging from $12 \%$ to $31 \%$ with a minority of these events are arterial. ${ }^{3,8}$ Some studies demonstrated that arterial thrombosis accounts for about $4 \%$ of thromboembolic complications due to COVID-19 infection. ${ }^{9}$ Any arterial segment can be involved in this condition, there have been reports of arterial thrombosis of brachial artery, radial artery, aorta, iliac and femoral arteries, superior mesenteric artery and even prosthetic vascular grafts as well. $^{3}$

The pathophysiology behind this hypercoagulable state is multifactorial. First, COVID-19 directly attacks vascular endothelial cells causing endothelial damage and activating the coagulation cascade which leads to vessels thrombosis in peripheral arteries and the aorta, and causes major vascular events such as acute arterial ischemia. ${ }^{10,11}$ Second, the association of COVID-19 with increased levels of pro-inflammatory cytokines (IL-2, IL-6, IL-7, G-CSF, TNF, IP-10, MCP1, MIP1- $\alpha$, etc.) in patients with a severe disease, which leads to cytokine release syndrome (CRS). ${ }^{2}$ Third, the immobility and hypoxia of critically ill patients.

In Italy, an observational study was performed to investigate the incidence and outcomes of 20 patients with acute limb ischemia which showed that the incidence of acute limb ischemia to be greater in the previous few months of 2020 compared with 2019, and 
they attributed the higher incidence to the increase in cases caused by thromboembolic disease associated with COVID-19. ${ }^{12}$

In our study, we observed that increased number of patients with ALLI compared to the same period (from November 1, 2019 to December 31, 2019) in the past year (1 patient vs 7 patients) which is 7-fold increase. Moreover, the number of cases of ALLI in the two months just prior to COVID-19 infection hospitalization was also 1 case in 2 months. Although ALLI is a well-known complication in critically ill patients, we noticed an increase in ALLI among COVID-19 patients in the ICUs (two cases in the last year compared to 5 cases in 2 months). All these data suggest the existence of a hypercoagulable state in patients with COVID-19 disease. $^{13}$

During the two months of this study, 7 patients (0.54\%) had concomitant ALLI and COVID-19 infection Figure 1. Two patients $(28.57 \%)$ presented to emergency department with ALLI and found to have asymptomatic COVID-19 infection, while 5 patients (71.43\%) developed ALLI during their admission due to COVID-19. The two patients with asymptomatic COVID-19 infection underwent successful surgical thrombo-embolectomy without mortality through femoral approach. One of them had recurrent ALLI to the same limb after 45 days of discharge and unfortunately she ended with below knee amputation. Arterial thrombotic events causing ALLI associated with COVID-19 infection are mainly located within microcirculation vessels, with associated high rate of recurrent thrombosis. Therefore, Mietto et al suggested a more aggressive regimen of prompt and full anticoagulation with intravenous UFH and selective intra-arterial thrombolysis. ${ }^{14}$ In the other hand, the five patients who developed ALLI during hospitalization had similarities. First, all of them had COVID-19 related pneumonia Figure 2. Second, they were managed in the critical care units. Third, they were all male had the traditional cardiovascular risk factors. Forth, they were unfit for revascularization surgery. Finally, all of them died within 24 hours of ALLI diagnosis. Woehl et al in their 4 case series underline the fact that patients predisposed to endothelial lesions (hypertension, male sex, smoking, diabetes) could be more prone to infection of the endothelium induced by the virus. ${ }^{13}$ This could explain the presence of traditional cardiovascular risk factors for atherosclerosis in all of our patients. Our result suggests a high mortality in COVID-19 related pneumonia which occurred within 24 hours of ALLI diagnosis. This confirms the fact that the prognosis of patients hospitalized with COVID-19 disease is often determined by the extent of pulmonary lesions and vascular complications can greatly affect outcome. ${ }^{13}$

This study has limitations regarding the retrospective nature and the small number of patients included. Further studies are needed to explore the relationship between COVID-19 infection and ALLI.

\section{Conclusions}

The prevalence of ALLI in patients infected with COVID19 was $0.54 \%$. We observed that patients with COVID-19
A

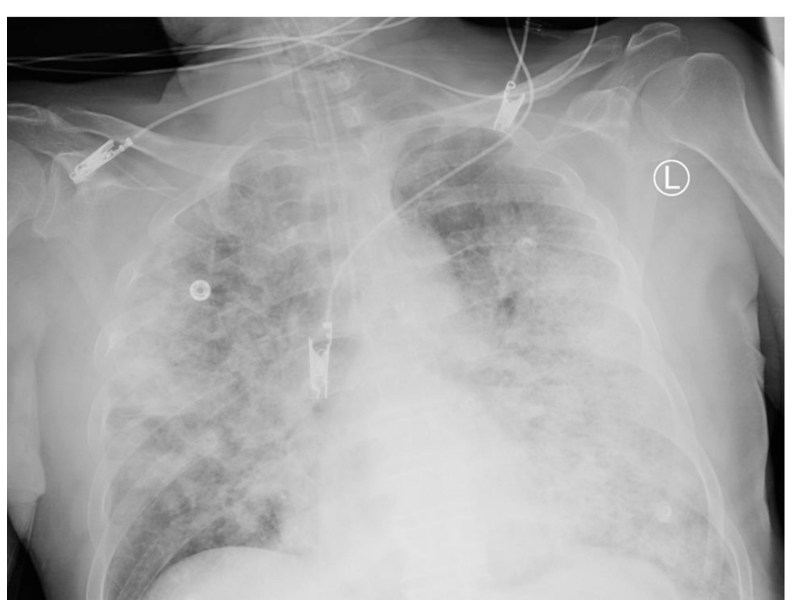

B

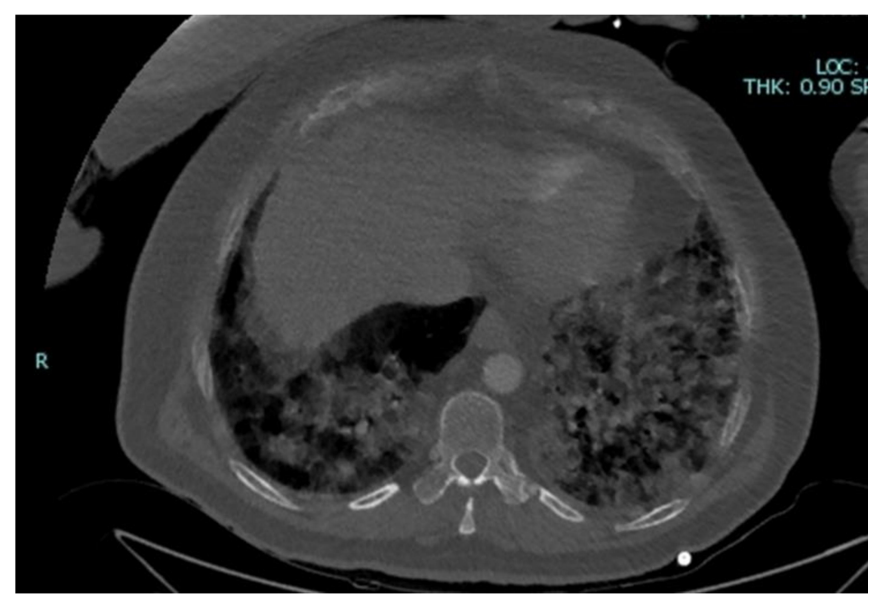

Figure I COVID-19 related pneumonia. (A) x-ray. (B) CT-scan. 
A

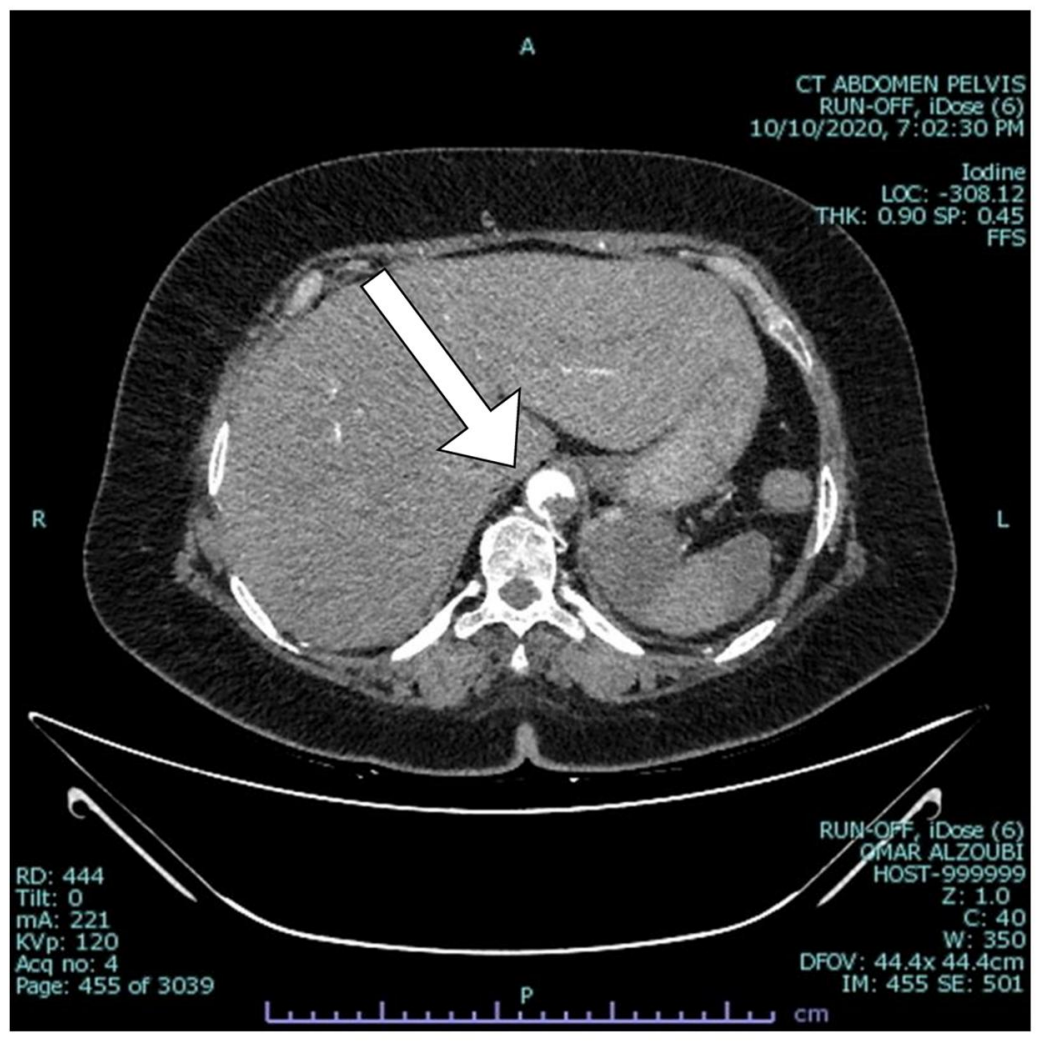

B

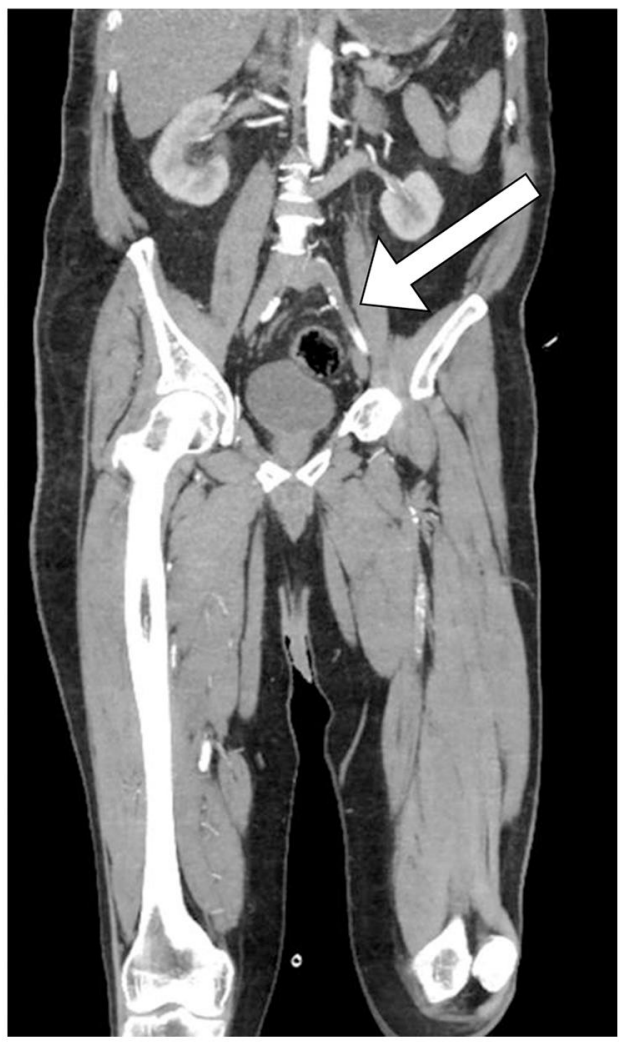

C

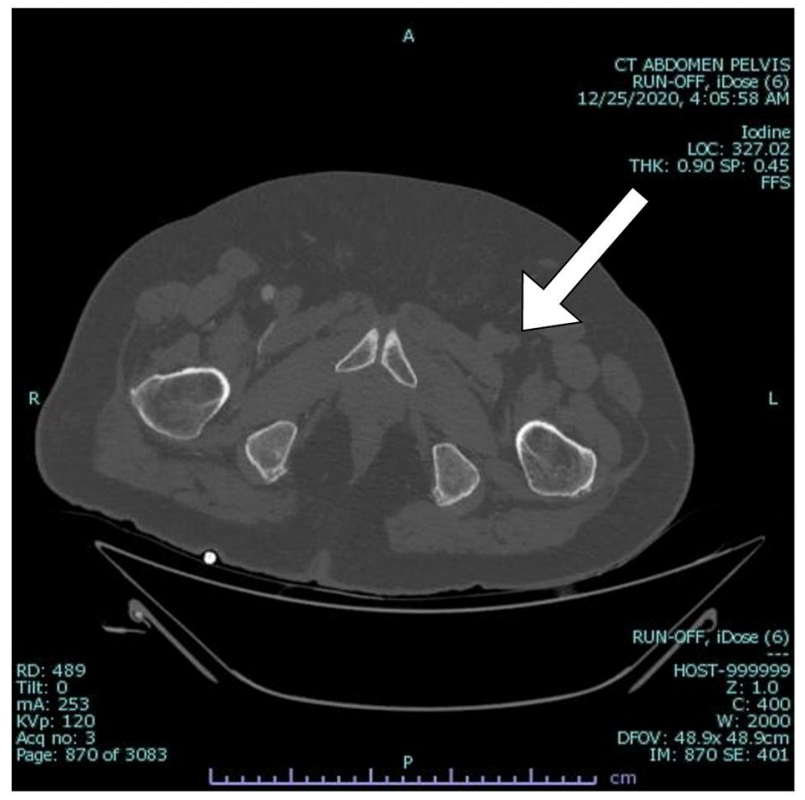

D

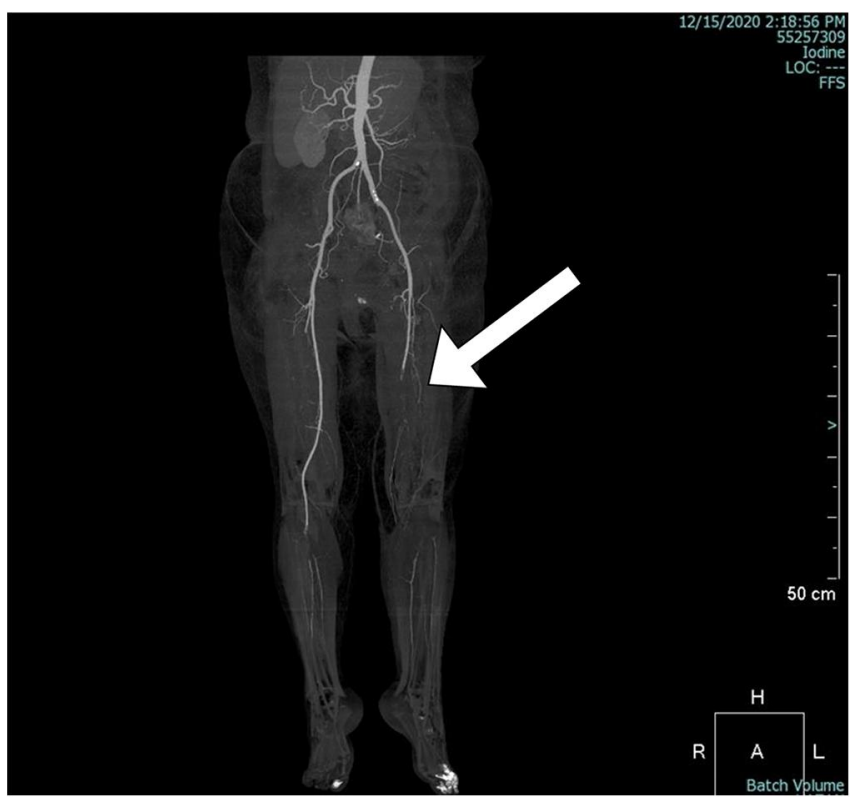

Figure 2 CT-Angiograms show different arterial segments involved in ALLI. (A) Aorta. (B) Aorto-iliac. (C) Common femoral artery. (D) Distal superficial femoral artery.

related pneumonia who develop ALLI have a high mortality. Further studies are needed to explore the relationship between COVID-19 infection and ALLI.

\section{Author Contributions}

All authors contributed to data analysis, drafting or revising the article, have agreed on the journal to which the article will 
be submitted, gave final approval of the version to be published, and agree to be accountable for all aspects of the work.

\section{Disclosure}

The authors report no conflicts of interest in this work.

\section{References}

1. Alajmi J, Jeremijenko AM, Abraham JC, et al. COVID-19 infection among healthcare workers in a national healthcare system: the Qatar experience. Int $J$ Infect Dis. 2020;100:386-389. doi:10.1016/j. ijid.2020.09.027

2. Hasan SA, Haque A, Nazir F. Acute limb ischemia: a rare complication of COVID-19. Cureus. 2020;12(11):e1148810.

3. Veerasuri S, Kulkarni SR, Wilson WR, Paravastu SCV. Bilateral acute lower limb ischemia secondary to COVID-19. Vasc Endovascular Surg. 2020;55(2):196-199. doi:10.1177/1538574420954301

4. Olinic DM, Stanek A, Tataru DA, Homorodean C, Olinic M. Acute limb ischemia: an update on diagnosis and management. J Clin Med. 2019;8(8):1215. doi:10.3390/jcm8081215

5. Baril DT, Patel VI, Judelson DR, et al. Outcomes of lower extremity bypass performed for acute limb ischemia. J Vasc Surg. 2013;58 (4):949-956. doi:10.1016/j.jvs.2013.04.036

6. Essa RA, Ahmed SK. Case report: acute lower limb ischemia in a recovered COVID-19 patient. F1000Research. 2020;9:1253. doi:10. 12688/f1000research.26603.1
7. Vacirca A, Vacirca A, Faggioli G, et al. Unheralded lower limb threatening ischemia in a COVID-19 patient. Int $J$ Infect Dis. 2020;96:590-592. doi:10.1016/j.ijid.2020.05.060

8. Mecl AV, Paz V, Navas ELSY, Baig I. A case of COVID-19associated acute limb ischemia. Chest J. 2020;8:520.

9. Bozzani A, Arici V, Tavazzi G, et al. Acute arterial and deep venous thromboembolism in COVID-19 patients: risk factors and personalized therapy. Surgery. 2020;168(6):987-992. doi:10.1016/j.surg.20 20.09.009

10. Anwar S, Acharya S, Shabih S, Khabut A. Acute limb ischemia in COVID-19 disease: a mysterious coagulopathy. Cureus. 2020;12 (7):9167

11. Canas EG, Gaibar AG, Lorenzo LR. Acute peripheral arterial thrombosis in COVID-19. Role of endothelial inflammation. $\mathrm{Br} J$ Surg. 2020;107(10):444-445. doi:10.1002/bjs.11904

12. Ahmad H, Shubair SM, Kruer J, Hatoum CA. Acute lower-extremity ischemia in a patient with COVID-19. Am J Case Rep. 2020;21:928471.

13. Woehl B, Lawson B, Jambert L, Tousch J, Ghassani A, Hamade A. 4 Cases of aortic thrombosis in patients with COVID-19. Case Rep. 2020;9(2):1397-1401.

14. Mietto C, Salice V, Ferraris M, et al. Acute lower limb ischemia as clinical presentation of COVID-19 Infection. Ann Vasc Surg. 2020;69:80-84. doi:10.1016/j.avsg.2020.08.004
International Journal of General Medicine

\section{Publish your work in this journal}

The International Journal of General Medicine is an international, peer-reviewed open-access journal that focuses on general and internal medicine, pathogenesis, epidemiology, diagnosis, monitoring and treatment protocols. The journal is characterized by the rapid reporting of reviews, original research and clinical studies

\section{Dovepress}

across all disease areas. The manuscript management system is completely online and includes a very quick and fair peer-review system, which is all easy to use. Visit http://www.dovepress.com/ testimonials.php to read real quotes from published authors. 